\title{
Assessed Result Relationship
}

National Cancer Institute

\section{Source}

National Cancer Institute. Assessed Result Relationship. NCI Thesaurus. Code C93454.

Specifies the link between an assessment (performed observation) and the results of other performed observations that the assessment is based on. 